\title{
Microtensile Testing of Wood - Overview of Practical Aspects of Methodology
}

\section{Ispitivanje mikrovlačne čvrstoće drva - pregled praktičnih aspekata metodologije}

\author{
Review paper $\bullet$ Pregledni rad \\ Received-prispjelo: 4. 4. 2013. \\ Accepted-prihvaćeno: 6. 2. 2014. \\ UDK: $630 * 812.76$ \\ doi:10.5552/drind.2014.1320
}

\begin{abstract}
Microtensile testing is a specific and delicate variant of standard tensile testing and is performed on small samples. Often also referred to as "thin strip" method, the testing of thin veneers is described in this paper with particular aspects of its field and scope of application, along with comments on reliability and variability of results. Experimental guidelines of the precise technique are presented as well.

The method consists of preparation of microtomed longitudinal wood sections, which may be treated or exposed to various conditions, agents or weathering, followed by tensile testing in a large number of replicas. Therefore, the reduction in size of samples shortens and/or facilitates the testing. Testing at zero span (the jaws of testing instrument being initially in contact) reflects to a greater extent the mechanical properties of the cellulose component, while the finite (usually $10 \mathrm{~mm}$ ) span test yields more information about matrix properties i.e. lignin intercellular material and the degree of fibre bonding.

This method has some shortcomings related to the fact that practical applicability is restricted to a small number of species, and that great skill is required to prepare the material, execute the testing and interpret the results. The method may be time consuming and technically demanding, depending on species and type of experiment.

However, further analyses of test strips (like colour measurements, chemical analytical testing, biodeterioration studies, etc.) render the method useful for a multi-aspect approach to specific studies on wood.
\end{abstract}

Key words: wood, thin strips, microtensile testing

\footnotetext{
SAŽETAK • Mikrovlačno je ispitivanje varijanta standardnoga vlačnog ispitivanja provedeno na malim probama. Često nazivano „,metodom tankih listića“, ispitivanje čvrstoće na vlak mikrotomiranih vrlo tankih furnira u ovom se članku opisuje uz posebno razmatranje polja primjene te metode, kao i uz komentare o pouzdanosti $i$ varijabilnosti rezultata. Članak također donosi eksperimentalne detalje i naputke za provođenje metode visoke preciznosti.

Prednost te metode očituje se u činjenici da je longitudinalne tanke mikrotomirane odsječke moguće zaštićivati različitim sredstvima (primjerice, impregnirati sredstvima za površinsku zaštitu), potom izlagati različitim utjecajima starenja i, konačno, podvrgnuti ispitivanju čvrstoće na vlak. Male dimenzije individualnih proba omogućuju ispitivanja na velikom uzorku. Ispitivanja na nultome početnom rasponu ispitnih čeljusti uvelike odražavaju mehanička svojstva celuloze, dok ispitivanja na određenom (najčešće 10-milimetarskom) rasponu daju informacije o ukupnim svojstvima materijala - ne samo o svojstvima mikrofibrila nego i o svojstvima veziva (lignina

${ }^{1}$ Authors are senior assistant and professor at Department for Furniture and Wood Products, Faculty of Forestry, University of Zagreb, Zagreb, Croatia.

${ }^{1}$ Autori su viši asistant i profesor Zavoda za namještaj i drvne proizvode, Šumarskog fakulteta, Sveučilišta u Zagrebu, Zagreb, Hrvatska.
} 
i hemiceluloze). Postupci izbora, pripreme, mikrotomiranja, uzorkovanja, izlaganja i ispitivanja opisani u ovom radu ključni su za postizanje pouzdanih rezultata (niskih koeficijenata varijacije), kako pri ponavljanju, tako i pri obnavljanju ispitivanja. Pravilno je mikrotomiranje, pak, ključan korak u procesu pripreme materijala, dok kontrola debljine osigurava kvalitetu pripremljenog materijala, a time i pouzdane i točne rezultate.

Nedostatak opisane metode jest to što je praktična primjenjivost smanjena na mali broj vrsta drva. Nadalje, metoda zahtijeva veliku vještinu i pozornost operatera pri pripremi materijala, provođenju ispitivanja i interpretaciji rezultata. Metoda je tehnički zahtjevna, a pokusi mogu biti dugotrajni. Unatoč tome, primjena te metode omogućuje relativno brz i pouzdan način ocjene kemijskih i strukturnih promjena, ispitivanja biološke razgradnje i drugih promjena tankih slojeva drva.

Ključne riječi: drvo, tanki listići, mikrovlačno ispitivanje

\section{INTRODUCTION}

\section{UVOD}

Cellulose, forming the skeleton of the essential structural units of wood - microfibrils - is itself extremely strong in tension because of the covalent bonding within the pyranose ring and between individual units. Hydrogen bonds within the cellulose crystalline and para-crystalline regions provide rigidity to the chain via stress transfer and allow the molecule to absorb shock by subsequently breaking and reforming when longitudinally stressed in tension. The hemicelluloses are found in the amorphous regions of the cellulose chains, particularly in peripheral wall layers of the wood cell, and are regarded as the connecting material between cellulose and lignin. Lignin itself is considered to be the adhesive of the cellulosic units and the bulking and rigidising material in respect to the structural cellulosic units. Following this, it is easy to understand that any chemical changes of wood constituents will weaken either the lateral bonds and affect the stress transfer, or the cellulosic units themselves. The mechanical parameter that reflects most sensitively these changes is tensile strength parallel to the grain (Ifju, 1964; Evans and Banks, 1990; Derbyshire and Miller, 1981; Derbyshire et al., 1996). It was demonstrated by numerous experiments that the tensile strength may precisely reflect the chemical changes of wood constituents due to exposure to biodegradation, acid conditions or weathering (Razckowski, 1980; Derbyshire and Miller, 1981; Evans and Banks, 1985; Evans et al., 1992a; Evans et al., 1992b; Lehringer et al., 2011). In order to record the fine changes, which are restricted either to a shallow surface layer or their distribution in depth of the sample, the microtensile testing technique can be successfully applied to various kinds of modification processes (Jirouš Rajković et al., 2004; Turkulin et al., 2006, Xie et al., 2007).

On the ultrastructural level, the densely packed secondary layers of the cell wall (esp. the S2 layer) are the strongest portions of the softwood tracheid. Those tubular cells, usually ca $3 \mathrm{~mm}$ (in spruce and pine) or $4.6 \mathrm{~mm}$ long (in western red cedar), are bonded to adjacent cells by the lignin rich middle lamella (or "compound middle lamella", CML, if the loose primary wall is understood to be a part of this bonding layer). Since the jaw separation of conventional testers is much greater than the microfibril length or the fibre length, the standardised tensile tests measured the combined mechanical properties of the microfibrils and matrix. It is of interest, therefore, to distinguish between the microfibril strength, or essential fibre strength, and the overall strength, where the inter-fibre bonding, especially in the CML region, plays a significant role. Attempts were made to separate the tensile properties of the cellulosic material from the intercellular material by determining wet strength values of the thin strips so that the CML would be excessively plasticised by water (Derbyshire and Miller, 1981; Evans et al., 1992b). Nevertheless, it proved necessary to carry out the investigations by means of tests in which the initial separation of the jaws could be set to a span less than the average length of cellulose microfibrils.

Microtensile testing is a specific and delicate variant of standard tensile testing and is performed on small samples. Often also referred to as "thin strip" method, the testing of thin microtomed veneers, described in this paper, monitors the surface changes and reactions (e.g. due to weathering), where the microtensile specimen represents a shallow surface layer.

Reduction in the size of tensile samples to microtensile samples, usually having thickness less than 100 $\mu \mathrm{m}$, is a useful technique when a fine anatomical distribution of wood properties (e.g. variations in chemical, mechanical and physical properties within a growth ring) is investigated, or when strength properties should be determined on material without great structural flaws.

\section{MICROTENSILE TESTING}

\section{MIKROVLAČNA ISPITIVANJA}

\subsection{General description}

\subsection{Opći opis}

There are two variants of the microtensile testing technique. The zero span test is a test in which the jaws or clamps are initially in contact. When this test is applied to wood strips, virtually all the microfibrils in the cross section bridge the gap between the clamps so that the test is principally a measure of microfibril strength. Since the microfibrils are the high-strength component of wood structure, the zero span tensile strength is greater than any value of tensile strength determined in a finite span test. It reflects to a greater extent the me- 
chanical properties of the cellulose component, while the finite span test yields information about matrix properties i.e. lignin/hemicellulosic intercellular material and the degree of fibre bonding.

The main advantages of the method compared to conventional mechanical techniques are small sizes of samples that allow the preparation of a great number of defect-free specimens from a limited source of material. The large surface-to-volume ratio of samples allows a uniform application of chemical and physical treatments throughout the cross section of the pieces. Finally, the ensuing failures can be microscopically studied on a cellular level. The large number of replicates meets the requirements of the statistical processing of data (Kennedy and Ifju, 1962; Derbyshire et al., 1996).

Short span tensile testing technique was originally developed for testing paper. The span must be shorter than the length of single fibres in a paper sheet. Testing at various short spans yields valuable information about the fibre strength, average fibre length, interfibre bonding and the general fibre quality in the paper sheet (Pulmac, 1992). Paper testers have been applied in wood science as a variant of microtensile testing (detailed review presented by Turkulin, 1996). The first attempt of using microtensile testing in wood research was to determine the influence of variations in ring orientation and anatomy on tension and compression failure of match-stick size bending specimens. The main conclusion of that study was that the specimens "should be of small dimensions so that anatomical differences might be large in comparison with overall dimensional values" (Forsaith, 1933). The method was also successfully applied for the analysis of differences in the density, compression, tension and bending strength of latewood and earlywood of softwoods (Ylinen, 1942). Microtensile technique was further applied in studying the effects of silvicultural treatments on the structural properties of wood that also led towards the idea of analyzing the within-ring variations in the density and mechanical properties of conifers from pith to bark (Kloot, 1952). Testing of successive rings of several conifers revealed that the tensile strength is greatly influenced by the orientation of the microfibrils in the S2 layer and that the reduction in the angle of microfibrils to the cell axis is closely linked to the increase in tracheid length, density, cellulose content and tensile strength (Wardrop, 1951). Wet and dry testing led Wardrop towards raising the important issue of the effect of water on the failure mode and to the speculations about the different influence of moisture on lignin bonding ability and the strength of the micelle structure.

Tracheid length and cellulose content are consistently correlated with the tensile strength, but the fibril angle is also a significant (inversely correlated) variable for latewood strength (Ifju and Kennedy, 1962). Authors noted that earlywood and latewood exhibit different types of failure since latewood has an indicated strength 3.2 times greater than that of earlywood, yet has only 1.8 times as much cell wall substance (Figure 1). The enhanced ability of individual cells of latewood to resist stresses may be attributed to the presence of a greater proportion of highly oriented secondary wall material.

Tensile properties are highly associated with specific gravity and wet ultimate tensile strength corresponds well with modulus of elasticity ( $\mathrm{r}=0.98$ ) (Ifju et al., 1965a; Wellwood et al., 1965). Wet tensile strength reflects very fine differences in ultramicroscopic architecture of the cell walls (Kennedy, 1966) as well as the variations in physical and mechanical intra-increment wood properties (Ifju, 1969). Specific gravity and wet tensile strength may exhibit a 4-fold increase from earlywood to latewood in conifers. Modulus of elasticity of wood samples correlates well with the dry tensile (finite span) strength going from earlywood to latewood in the growth ring (Nordman and Quickström, 1969). Ifju et al. (1965a) came to the same conclusion for wet testing.

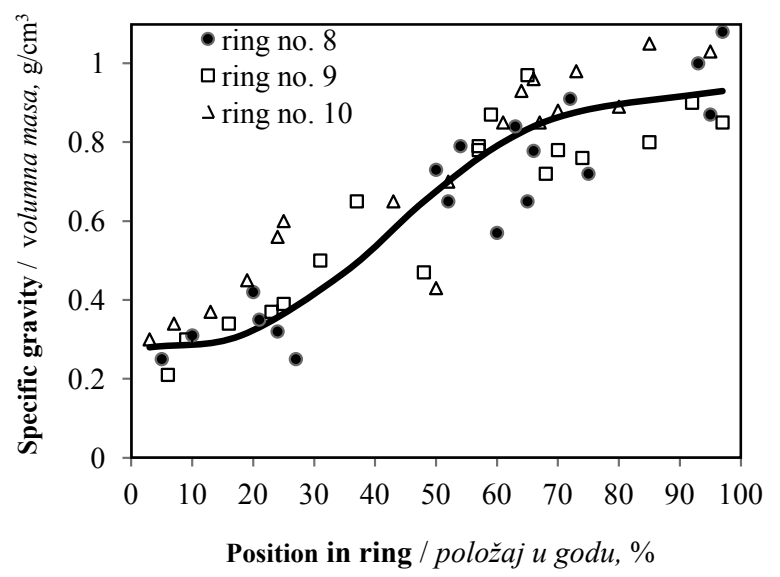

Figure 1 Variation in specific gravity of wood in three adjacent increments in loblolly pine (Pinus Taeda L.) (Ifju and Kennedy, 1962).

Slika 1. Varijacije volumne mase drva triju susjednih godova borovine (Pinus Taeda L.) (Ifju and Kennedy, 1962)

Mark $(1965,1967)$ developed a radially cut sample, which consisted of only one complete row of tracheids ( $25 \mu \mathrm{m}$ thick), 8 to 10 cells $(200 \mu \mathrm{m})$ in width, and was free of rays in its constricted neck area. He determined the minute stress and strain values, microfibrils angles and proportion of particular cell wall layer in the net cross-sectional area, chemical composition and packing density distribution within the cell wall. Based on such analysis, the tensile properties can be associated with chemical wood constituents, their proportions and organization (distribution in the layers, proportions of layers in the net cross-sectional area, microfibril angle and the bond between microfibrils etc.). It forms a basis for the interpretation of the failure mode i.e. anticipates the intention that the fractographic evidence reveals the chemical decomposition of the cell wall (Turkulin and Sell, 2002).

Problems that greatly influence the results of the micro-tensile strength measurements are the variations in specimen geometry (particularly uniformity of thickness), angle of grain, density, structural characteristics, etc. (Biblis, 1969). This author stressed that the 
wet strength of $100 \mu \mathrm{m}$ thick samples is on average 50 $\%$ lower than the strength of green standard samples, or of the samples containing entirely earlywood or latewood zones. He attributed those differences to either microtoming damage or to the occurrence of longitudinally and/or obliquely cut cells on either side of microspecimen, which causes irregular distribution of combined stresses, rather than uniform longitudinal tension. This conclusion is important, since some authors (Forsaith, 1933; Kloot, 1952) believed that the strength of microspecimens, because of the minimization of the inherent flaws, should be greater than that of standard samples. The effect he noticed is however much more evident in wet than in dry testing, as the water plasticises the middle lamella to a greater extent than the cell walls. The relative influence of the middle lamella strength on the overall strength increases with the reduction in thickness. Regardless of the possible microtoming damage, there is a high degree of association between tensile properties and thickness of microtomed sections up to $200 \mu \mathrm{m}$ thickness (Biblis, 1970). This is a good confirmation of Mark's analysis (Mark 1965, 1967) of the influence of the proportion of the sliced cells in the cross section on the reduction in overall strength.

\subsection{Assessment of photodegradation by application of microtensile testing}

2.2. Ocjena fotodegradacije primjenom mikrovlačne tehnike

Microtomed wood sections can also be applied in monitoring photodegradation (Kalnins, 1966; Raczkowski, 1980; Derbyshire and Miller, 1981). Most recent comprehensive work in that area may be found in the thesis of Živković (2011). Raczkowski (1980) assessed the surface ,corrosion“ based on the long range tensile testing of $100 \mu \mathrm{m}$ thick spruce (Picea abies, L.) strips to evaluate the combined effects of sunlight and atmospheric pollutants. Derbyshire and Miller (1981) additionally observed fungal colonization, which was negligible in dry and sunny periods, but very intensive in late autumn and winter. They also tested the influence of different spectral regions of solar radiation on the photodegradation rates. Thin strips were used for tensile strength testing in both dry and wet conditions, modulus determination, SEM fractographic analysis and determination of the cellulose disperse viscosity. Their main conclusion was that the tensile measurements on weathered strips yield a more accurate and relevant assessment of weathering damage than observations of colour change and the breakdown of microstructure. They were able to distinguish between the initial lignin breakdown and more profound effects of the depolymerization of the cellulose constituent, the latter being monitored by strength changes over zero span and by cellulose disperse viscosity changes. Additional evidence to explain the weathering process was found in microscopic analysis, but the structural changes, especially in the early weathering phases, did not prove such a sensitive parameter as the tensile strength loss. Turkulin later showed (Derbyshire et al., 1996; Turkulin and Sell, 2002) that microscopic evidence can essentially corroborate the complete comprehension of the failure origin and mode.

The thin strip technique has been extensively applied by other researchers in studies of the degradation of exposed wood surfaces. Evans and Banks (1985, 1988) successfully examined the effects of hot water on wood degradation, and the effect of dilute acids (Evans and Banks, 1985). Testing in wet and dry conditions enabled speculations about the nature of the failure, i.e. the influence of water on the inter-fibre bonding and on the microfibrilar bonding. Derbyshire and Miller (1981) and Evans and Banks (1990) came to the same conclusions that the chemical and ultrastructural changes accord with the losses in tensile strength of thin strips and that the failure mode can reveal the nature of chemical decomposition of wood constituents.

Evans et al. (1992a, 1992b) showed that finite span testing reveals delignification more rapidly than zero span testing. This was further confirmed by chemical analysis of the lignin content and by FTIR spectral analysis performed on weathered strips and subsequent SEM analysis which contributes to the explanation of the effect of chemical changes to the structural integrity and consequent strength characteristics.

Derbyshire and Miller also continued their work on weathering using extensively the thin strip method. They investigated the effect of temperature (Derbyshire et al., 1997) on photodegradation rates and applied the method to the assessment of photostabilisers of wood. They also evaluated artificial weathering devices and demonstrated that they offer a consistent, reliable and precise means of determining photodegradation rates for wood (Derbyshire et al., 1995, 1996). The strength changes were shown to be consistent with fractographic evidence of the structural changes in wood, namely with cell delamination, development of brittleness and loss in cell wall integrity (Turkulin and Sell, 2002). Thin strip technique was also used to investigate the effect of moisture on photodegradation rates (Turkulin et al., 2004), which proved to be a significant factor in accelerating photodegradation of wood by increasing the rates of strength loss.

Jirouš Rajković et al. (2004) and Turkulin et al. (2006) sucessfuly applied the thin strip method to test the effectiveness of several surface treatments, as well as to monitor the depth profile of photodegradation. Radial, but also pure tangential earlywood strips of softwood, were assembled in packs of three. The first strip in the pack was either surface treated or covered with free film of clear stain. The strips reflected very sensitively the effects of photodegradation and gave valuable information on the effectiveness of tested protective materials. 


\section{DESCRIPTION OF THE METHOD}

\section{OPIS METODE}

\subsection{Material selection for preparation of radial strips}

3.1. Izbor i priprema materijala za radijalne listiće

If strips are to be microtomed from the radial surfaces of small wood blocks (radial strips), rectangular wood blocks should be straight grained, free from all visible defects, machined and smooth planed. Additionally, to ensure more uniform stress distribution between the latewood bands and within the whole strip, test specimens should be prepared with the same number of latewood bands having earlywood zones at their edges (Figure 2). Since the stress during microtensile testing is much greater in latewood than in earlywood, strips with latewood band at their edges would determine the point of ultimate stress and affect the result (Kufner, 1963; Turkulin and Sell, 2002). Typical material based on density, ring width and latewood portion consists of 4 to 5 rings per $10 \mathrm{~mm}$ width. Optimal dimensions of the block for microtoming are $100 \mathrm{~mm}$ in length, $40 \mathrm{~mm}$ in height and $10 \mathrm{~mm}$ in thickness. Properly microtomed block of $40 \mathrm{~mm}$ width yields about 300 strips of nominal thickness of $80 \mu \mathrm{m}$. To obtain a sufficient number of strips for a series of trials, it is often necessary to section more than one block. Blocks that are adjacent in longitudinal direction (prepared from the same stick) are favoured in order to avoid the differences in density, number and the overall width of the annual rings and inclusion of uneven proportions of the latewood that could influence the results (Figure 3). Reliability of a test may be enhanced by assembling batches of strips from a mix of all the blocks using the same pattern of selection (e.g. $2+2+1$ from three blocks, or 1 strip from each of five blocks).

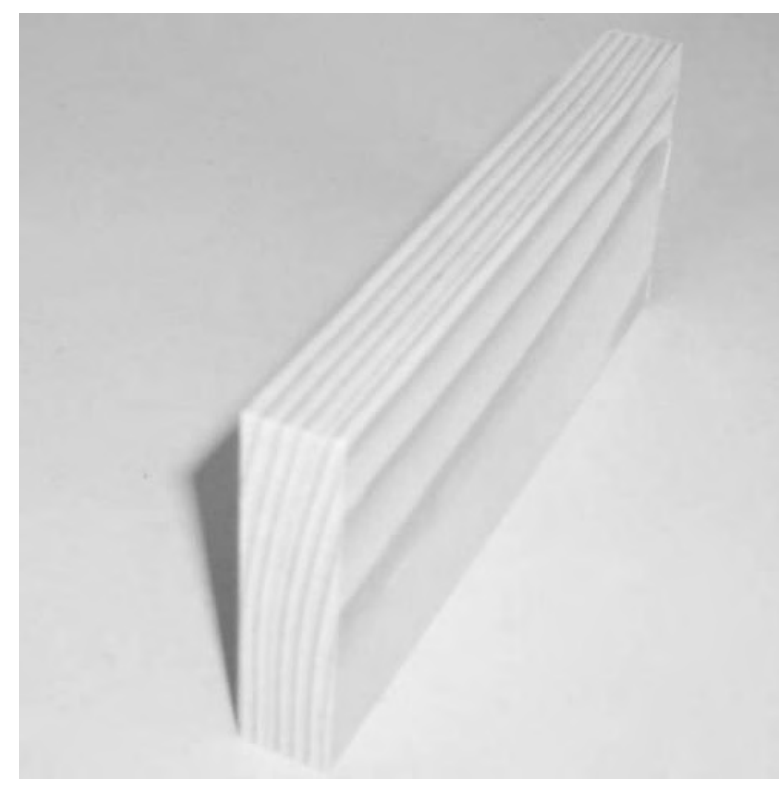

Figure 2 Fir wood block for production of radial strips Slika 2. Blok jelovine za izradu radijalnih listića

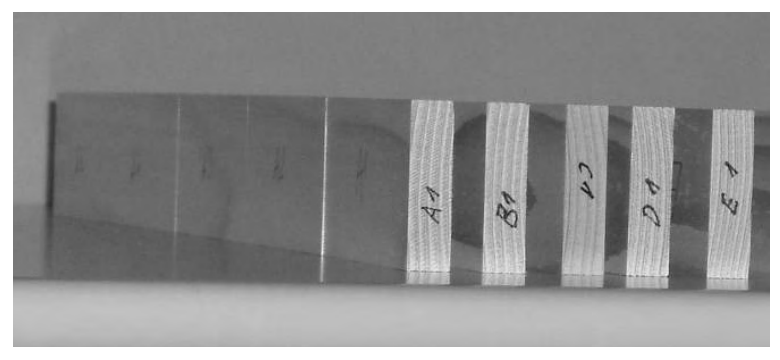

Figure 3 End-grain scans of fir wood blocks prepared from five sticks (letter mark on the block denotes the stick, number mark denotes a position within the stick) Slika 3. Blokovi jelovine pripremljeni od pet štapića (slovo na bloku označava štapić, a broj označava položaj unutar štapića)

\subsection{Preparation for microtoming}

\subsection{Priprema za mikrotomiranje}

Prior to microtoming, the blocks are plasticised by means of waterlogging. The procedure (described in detail by Turkulin, 1996) is conducted in a vessel where blocks are vertically positioned, separated with Perspex spacer bars so that all the surfaces are exposed to water, loaded with lead weights to prevent their floating and waterlogged until full saturation using vacuum under ambient temperature. Desiccator is evacuated for at least 30 minutes, after which the water is gradually infused without releasing the vacuum until the blocks are fully immersed. The vacuum is maintained for the next $2-4$ hours, after which the ambient pressure is restored by admitting the air into the vessel and leaving the blocks soaking over night. Afterwards the blocks are exposed to several changes of vacuum of $4-5 \mathrm{~mm} \mathrm{Hg}$ and atmospheric pressure in the $10-15$ $\%$ solution of ethanol until no air bubbles appear on the surfaces of the blocks after re-establishing the vacuum. For permeable species, soaking overnight is usually ample time to achieve full penetration of the blocks, whereas for impermeable species (like Pine heartwood, Western red cedar or Norway spruce) the vacuuming in water usually needs to be repeated for the next several days. When completely saturated, blocks normally show no tendency to float. Blocks are kept fully immersed until required for sectioning, but not for longer than 10 days. The water should be changed occasionally and fresh ethanol added to prevent developing any mould or bacterial growth.

\subsection{Microtoming}

3.3. Mikrotomiranje

The strips may be microtomed with a conventional sliding microtome, using either conventional knives or knives with exchangeable blades. The most important factors of good microtoming quality are the condition (sharpness) of the blade (Turkulin, 1996), cutting angle (Dinwoodie, 1966; Keith and Côté, 1968; Kennedy and Chan, 1970; Turkulin, 1996), vibrations (Wachtel et al., 1966) and condition of microtomed surface. Bluntness of the cutting edge, which is the most influencing parameter for the quality of cutting, causes compression of the wood underneath it (mainly on the latewood bands) and results in warped strips. 
This is very significant for the thin strip method since the tensile strength is mainly determined by properties of the latewood. The best slicing results on softwoods are obtained when the inclination angle of the knife is $16^{\circ}$ (tilt angle on the microtome scale), the draw angle (the angle between the blade and the grain of wood) is $22^{\circ}$ and polishing angle of the blade $18^{\circ}$. Smaller inclination angles cause the blade to compress the wood that forms the next strip, while angle greater than $18^{\circ}$ yields coarser strips. Vibrations during microtoming, caused by improper or loose block mounting, usually cause nonuniform thickness of the strips and result in faster blunting of the knife. Condition of the blade can also be tested by occasional attempts to cut only 10 to $15 \mu \mathrm{m}$ thick strips. If such strips were inconsistent or not complete over the whole surface, the blade should be exchanged. To enable successful microtoming, the surface should be continuously lubricated with a mixture of $10 \%$ ethanol in distilled water by maintaining the film of liquid on the cutting surface.

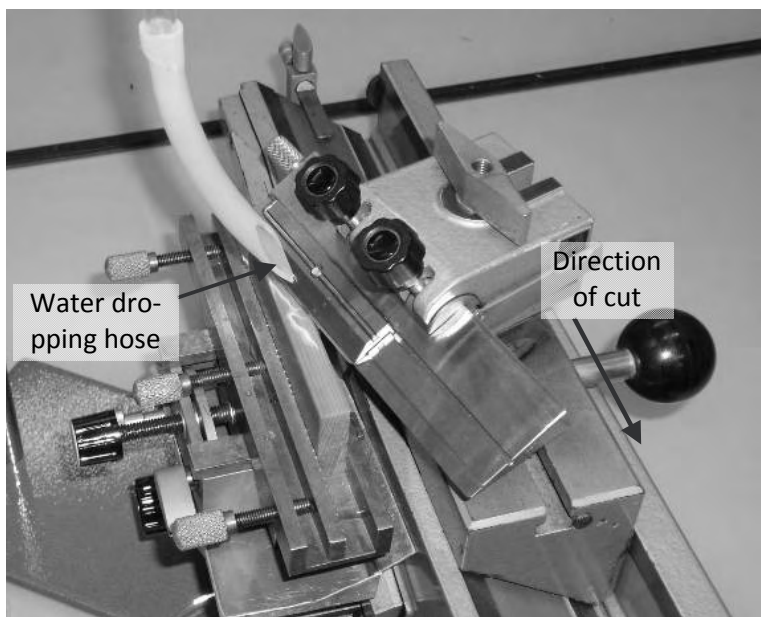

Figure 4 Appearance of the knife with exchangeable blades and the principle of lubricating wood surface during microtoming

Slika 4. Prikaz noža s izmjenjivim oštricama i načina močenja proba tijekom mikrotomiranja

Optimal thickness of the radial strips is around 80 $\mu \mathrm{m}$ for it is proved to yield the optimum strength values when Pulmac paper testing instruments are used. The softwood strips of such thickness usually consist of two rows of tracheids, of which at least one would be complete. Strips thicker than $90 \mu \mathrm{m}$ cause ultimate loads to failure that fall out of the range where the rate of loading on Pulmac paper testers is constant, and may cause slippage from the clamps of standard tensile machines equipped with micro-tensile unit. Latter cases render the results which are unreliable, while testing of strips thinner than $60 \mu \mathrm{m}$ generally causes great variability of the results.

\subsection{Preparation of tangential strips \\ 3.4. Priprema tangentnih listića}

Due to uneven distribution of physical properties within the softwood ring and practical problems of microtoming, it is not possible to use or accept all the strips microtomed from earlywood or latewood portion within a single annual ring. Therefore, only the strips are selected that represent the relevant incremental zones within the tree ring. While the density of the late wood is almost constant, the early wood density is low at the initiation of the ring, then constant only up to ca $40 \%$ of the growth ring, after which it increases up to several times (Ifju et al., 1965b; Kennedy, 1966; Ifju, 1969; Wellwood et al., 1965). Greater problems occur with species with gradual ring transition than with species with abrupt transition from earlywood to latewood. Practical microtoming problems may be manifested as non-uniform properties over their entire length of the strip and the increased number of strips required for replication.

In order to get strips with as uniform initial properties as possible, that may later give reliable results, earlywood strips can be taken from the zone with position of approximately 5 to $40 \%$ in the ring width, and latewood strips from the position of 75 to $95 \%$ within the ring (Turkulin, 1996; Jirouš Rajković et al., 2004). This also means that small ring widths further aggravate the microtoming process and reduce the number of usable strips. Contrary to microtoming radial strips, blocks for tangential strips should be machined with cutting plane as parallel as possible to the tangent to the ring boundary, since any misalignment requires additional sections prior to obtaining uniform strips. Preparation of strips containing only earlywood is easier and more efficient if the blocks have wide annual rings. The use of pure earlywood material can be justified by the fact that the earlywood is much more prone to weathering and that the effects of modifications on improvement of surface properties could then be successfully performed solely on earlywood strips.

\subsection{Thickness measurements and variability}

3.5. Mjerenje debljine i njezina varijabilnost

Proper microtoming is a crucial point in preparation procedure in thin strip method, ensuring low variability of results. Furthermore, uniform and even thickness of the strips reflects the quality of the testing material and guarantees reliable and accurate tensile testing results.

After natural drying, thickness of the strips is checked on all strips in order to avoid undesirable aberrations of tensile strength within and between the batches of strips. Strips that do not fit into a certain thickness range are discarded and selected material is additionally checked for thickness in order to define the concordance of the strip thickness with the nominal value. This is important as it enables comparisons of the material from different blocks.

The thickness is usually measured with electronic thickness gauge having a semi-spherical tip and the accuracy $\pm 0.1 \mu \mathrm{m}$. Measurements are taken every $2 \mathrm{~cm}$ along the strip or along the entire strip length. To avoid incorrect readings due to excessive pressure of the gauge tip to wood strips (that could cause deformations, especially on earlywood bands), the gauge should exert minimum available force on the tip. All 
the strips that do not fall into the range of $\pm 5 \%$ shall be rejected. However, provided that the sectioning is performed correctly, not more than $10 \%$ of radial strips having nominal thickness of $80 \mu \mathrm{m}$ fall out of the range of $\pm 3 \mu \mathrm{m}$, whereas tangential earlywood strips vary even less (only $\pm 2 \mu \mathrm{m}$ ) (Turkulin, 1996).

\section{Application of the Pulmac short span paper tester \\ 4. Primjena Pulmac kidalice}

The Pulmac machine is operated pneumatically using compressed air to provide both the load and the clamping pressure of the jaws. The basic machine offers the facility to carry out tests at initial spans in the range 0 to $1.6 \mathrm{~mm}$. When adapted, long range tensile tests at $10 \mathrm{~mm}$ initial span can also be carried out. The Pulmac tester can be additionally equipped with a transducer, which allows the recording of strain, i.e. determination of the modulus of elasticity.

Particular advantages of the use of Pulmac testers are:

- ability to control the clamping pressure

- precise alignment of the sample in the clamps, parallel to the load direction

- low risk of damaging the samples by clamping (virtually no failure at the clamps in finite span testing)

- considerable savings in time during tensile testing.

The main value representing tensile properties is the ultimate breaking load in tension parallel to the fibres. This approach is advantageous compared to calculation of tensile stress because of problems in defining the cross-sectional area of a cellular material and of determining the changes of a cell wall thickness after degradation. Reduction in the cross-sectional area may arise either due to weathering or as a consequence of chemical or biological degradation. The same net cell wall area can be represented by different formation of cells (e.g. two rows of complete cells are much stronger than one row of complete cells lined by two rows of half-split cells). Furthermore, weathering will cause much greater strength loss than the reduction of the cross-sectional area. For this reason, instead of recording absolute tensile stress strength values, it is very often more convenient and interesting to express the results as relative changes (be it retained strength or relative strength loss).

Two main variables in the operation of the Pulmac testers are the rate of loading and the clamping pressure of the jaws. To achieve an accurate value of the tensile strength of the sample, it is essential to achieve the clamping pressure of the jaws high enough to prevent the slippage of the sample whilst not being so high as to cause physical damage to the delicate sample. Too low or too high a clamping pressure would result in a measured failure load lower than the true failure load (Figure 2).

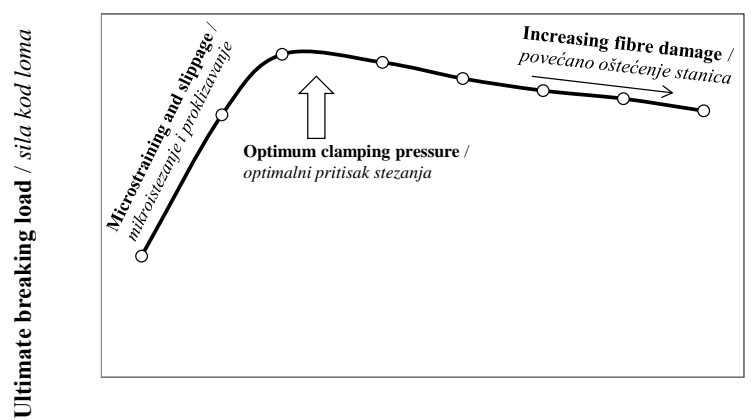

Clamping pressure / pritisak stezanja

Figure 5 Influence of clamping pressure on the ultimate breaking load (Pulmac, 1992)

Slika 5. Utjecaj pritiska stezanja na najveću silu loma (Pulmac, 1992)

In $10 \mathrm{~mm}$ span testing the choice of clamping pressure is relatively straightforward and less critical than in $0 \mathrm{~mm}$ span testing. Too high a clamping pressure will cause the failure in the jaw or in the part of the strip immediately adjacent to the edge of the jaw. Such failure appears as a straight line, possibly with small "teeth" on it, across all or a part of the width of the strip. Too low clamping pressure results in slippage of the whole strip under one jaw, or slippage of portions of the strip under the jaws before the moment of failure. It is therefore recommended to perform preliminary testing at lower pressures, and increase the pressure until no slippage occurs and the failure spreads in the middle portion of the strip, or across the area between the jaws. This will completely eliminate the risk of failure at the grips - which was a great concern of several authors (Ifju et al., 1965a; Michon et al., 1994). Should the ray appear across the body of the sample, thus presenting the discontinuation of axial, tensionloaded cells, the failure spreads across the border between the ray cells and tracheids. The load to failure is regularly much below the average for the batch, and such samples should be discarded. The inclusion of longer ray cells in the loaded area should be avoided by microtoming the strips at certain small angle to the radial plane (usually $3-5^{\circ}$ ). Further care should provide that the ray lines are excluded from the loaded areas during sectioning of the strip into testing samples.

In $0 \mathrm{~mm}$ span testing, the failure occurs in the very narrow area in between the jaws, and within the fibres under the edge of the jaws. It is therefore impossible to apply the "failure-at-the-grips" criterion described in $10 \mathrm{~mm}$ span testing. The optimum setting of clamping pressure is associated with the maximum load to failure that is determined by carrying out several preliminary tests at different pressures, additionally confirmed by visual checks on the fractured sample. A proper zero span failure should result in the failed edge being a straight line with up to approximately $0.5 \mathrm{~mm}$ long "teeth" on it. Very "clean" failure indicates too high a clamping pressure, whereas longer teeth, often triangle-shaped, occur generally at too low a clamping pressure, when the portions of the strip had been pulled out under the whole clamp stop. 
The appearance of finely jagged failure line is caused by so called "residual span", indicating that some fibrils were not clamped by both jaws. In that case, the span is not zero but a small finite span with increased role of interferer bonding and reduced ultimate load. Consequently, the difference between zero and finite span values is reduced. Microscopic examination during preliminary testing may reveal whether the adequate mode of failure was obtained, without excessive damage to the sample (Figure 6).

One should take into account that clamping pressure during the test should be adjusted to changes in tensile strength. As material becomes weaker or more brittle with prolonged exposure, the same clamping pressure will cause ever greater damage to the delicate specimens and, consequently, higher rates of strength loss with time.

A characteristic type of failure occurs sometimes in the initial strength determination described as "combed" failure (Figure 7). Due to the differences in compressibility of earlywood and latewood regions, or differences in thickness of those portions due to im- proper microtoming, the earlywood bands are not firmly gripped by the jaws. The failure in the stressed zone occurs in latewood portions, while the earlywood portions are separated along the ring border and transition zones and slip through the jaws. This behaviour has been noted previously by Law and Koran (1979). Where possible, all the strips from the block with described anomaly should be discarded. However, the occurrence of this failure mode need not necessarily mean that the initial testing results are invalid: the strength of the strips is in any case predominantly determined by the strength of the latewood bands, and as the failure and slippage of earlywood does not occur before the failure of the latewood portions, it is likely that the earlywood fibres bear the load and contribute to the stress distribution. Their failure and slippage occur after the ultimate load to failure has been reached, and are associated with the crack propagation phase. The strength of such strips, indeed, was not noted to be lower than is the strength of strips with "normal” failure (Turkulin, 1996).
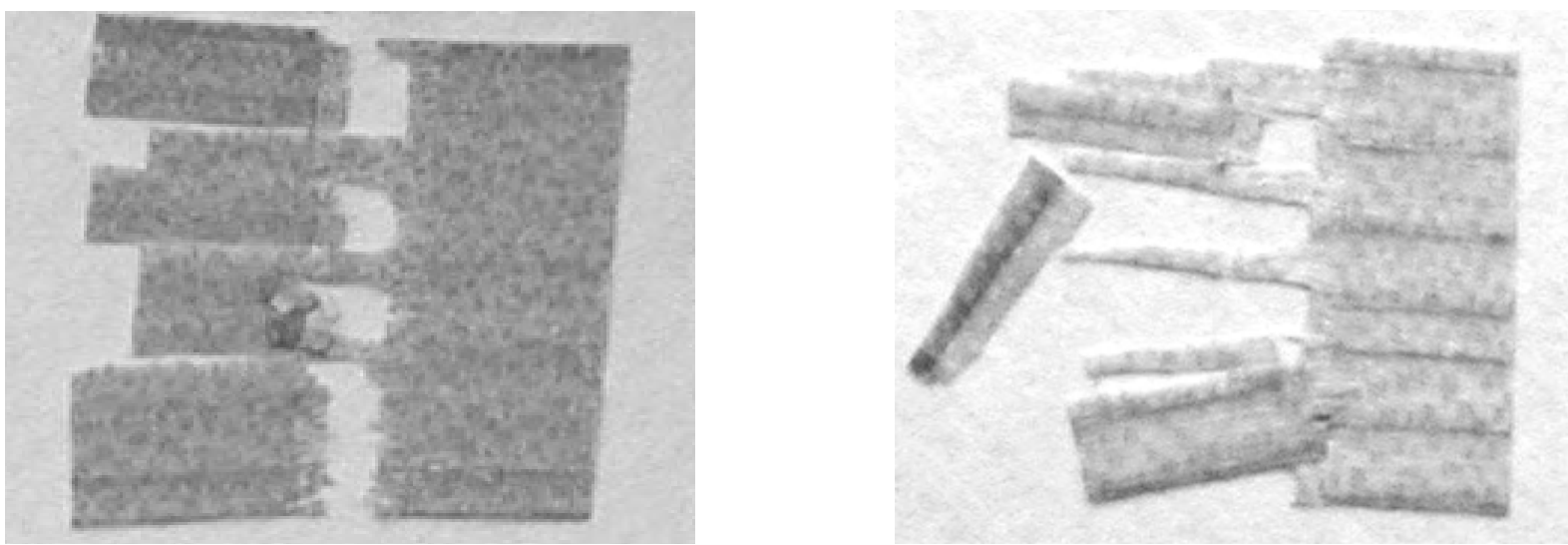

Figure 6 Schematic presentation of a "combed" failure in zero span testing due to different compressibility of early wood and late wood bands

Slika 6. Shematski prikaz “češljastog” loma pri ispitivanju na nultom rasponu zbog različite stlačivosti pruga zona ranoga i kasnog drva
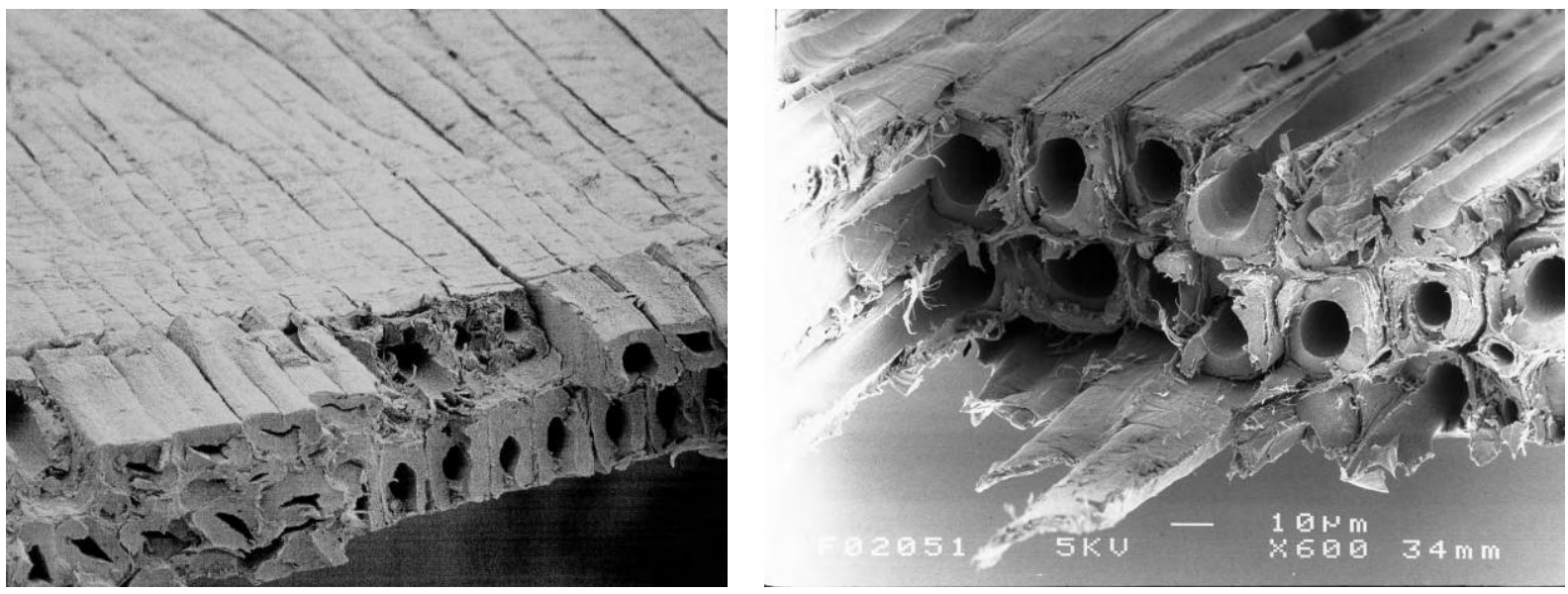

Figure 7 Latewood bands after tensile testing at zero span of clamps. Left image shows the damage and compression of wood tissue imposed by the clamp stop. Right image depicts regular failure mode.

Slika 7. Pruge kasnog drva nakon vlačnog ispitivanja na nultom rasponu hvataljki. Lijevo se vidi da je stopica čeljusti ispitnog stroja zgnječila i oštetila vlakanca, što uzrokuje lom pri manjim vlačnim silama. Desno je pravilan lom bez oštećenja staničja. 
Careful preparation, microtoming, selection, batching, exposing and testing procedures as described here, enable to attain sufficient precision of the method and acceptably low coefficients of variation (Derbyshire et al. 1995). The $10 \mathrm{~mm}$ span test is more affected by unpredictable factors such as micro-flaws in the strips and the speed and path of crack propagation; therefore coefficients of variation of up to $19 \%$ can be expected in untreated material. Where possible, material should be chosen with an initial strength coefficient of variation not much higher than $10 \%$. Coefficients of variation for degraded material are usually higher and increase with exposure time.

Variability of the strips is highly influenced by general macroscopic physical properties (Table 1). Since these properties can differ significantly even between blocks taken from the adjacent positions in the stem or in the board, they should be carefully checked. Another, particularly important factor is the microfibril angle in S2 layer (its significance is best presented in comprehensive work by Mark, 1967) and variations between intraincrement densities (as shown by Ifju, 1969, or Wellwood et al., 1965). These properties are not easily measured, but the choice of blocks and their mutual position (relevant to the cambium initial, or to the position in the board) may assure the uniformity of essential physical properties of the material. Therefore, great care must be taken if comparison is being made between the results of trials performed on material from different groups of blocks.

Table 1 Factors causing irregularities of the results

Tablica 1. Čimbenici nepravilnosti rezultata

\begin{tabular}{|c|c|c|c|c|}
\hline \multicolumn{5}{|c|}{ 1) Variability of strips tested / Varijabilnost ispitnih listića } \\
\hline $\begin{array}{l}\text { a) choice of material / izbor } \\
\text { materijala } \\
\text { - density / gustoća } \\
\text { - ring width / širina goda } \\
\text { - latewood proportion / udio } \\
\text { kasnog drva } \\
\text { - width, height, number and } \\
\text { distribution of rays / širina, } \\
\text { visina, broj i raspored } \\
\text { trakova } \\
\text { - latewood density and } \\
\text { difference between early- } \\
\text { wood and latewood densities } \\
\text { / gustoća kasnog drva i } \\
\text { razlika između gustoće } \\
\text { ranoga i kasnog drva } \\
\text { - microfibril angle (particu- } \\
\text { larly in latewood) / kut } \\
\text { uspona mikrofobrila } \\
\text { (pogotovo u kasnom drvu) }\end{array}$ & $\begin{array}{l}\text { b) material } \\
\text { preparation process } \\
\text { / tijek pripreme } \\
\text { materijala } \\
\text { - drying stresses } \\
\text { and defects / } \\
\text { naprezanja } i \\
\text { oštećenja tijekom } \\
\text { sušenja } \\
\text { - saturation } \\
\text { procedure / } \\
\text { postupak impreg- } \\
\text { nacije }\end{array}$ & $\begin{array}{l}\text { c) structure of strips / } \\
\text { struktura listića } \\
\text { - number of rings, position of } \\
\text { latewood bands / broj godova } \\
\text { i položaj zona kasnog drva } \\
\text { - angle of cutting (grain } \\
\text { angle) - amount and variation } \\
\text { / kut rezanja (otklon žice) - } \\
\text { njegov iznos i odstupanja } \\
\text { - lateral angle (between ring } \\
\text { boundary and cutting plane) } \\
\text { - amount and variation / } \\
\text { pobočni kut (između granice } \\
\text { goda i ravnine rezanja) - nje- } \\
\text { gov iznos } i \text { varijacije } \\
\text { - position of tangential strips } \\
\text { within tree ring / položaj } \\
\text { tangentnog listića unutar } \\
\text { goda }\end{array}$ & $\begin{array}{l}\text { d) microtoming } \\
\text { errors - slip lines } \\
\& \text { delamination / } \\
\text { greške mikroto- } \\
\text { miranja - linije } \\
\text { nagnječenja } i \\
\text { delaminacija }\end{array}$ & $\begin{array}{l}\text { e) thickness } \\
\text { of strips / } \\
\text { debljina } \\
\text { listića }\end{array}$ \\
\hline
\end{tabular}

2) Variations in exposure conditions (for weathered material) / Varijacije u uvjetima izlaganja (za izlagani materijal)

\begin{tabular}{|l|l|l|}
\hline $\begin{array}{l}\text { a) radiation dose received / } \\
\text { primljena doza zračenja }\end{array}$ & $\begin{array}{l}\text { b) moisture conditions during exposure / uvjeti } \\
\text { vlažnosti tijekom izlaganja }\end{array}$ & $\begin{array}{l}\text { c) temperature during exposure / } \\
\text { temperatura tijekom izlaganja }\end{array}$ \\
\hline
\end{tabular}

3) Tensile testing parameters / Patametri ispitivanja vlačne čvrstoće

\begin{tabular}{|l|l|l|l|l|}
\hline $\begin{array}{l}\text { a) loading rate / brzina } \\
\text { opterećenja }\end{array}$ & $\begin{array}{l}\text { b) clamping pressure / } \\
\text { pritisak hvatanja }\end{array}$ & $\begin{array}{l}\text { c) climate conditions } \\
\text { during testing / } \\
\text { klimatski uvjeti } \\
\text { tijekom ispitivanja }\end{array}$ & $\begin{array}{l}\text { d) mechanical } \\
\text { damage due to } \\
\text { handling / } \\
\text { mehanička } \\
\text { ośtećenja pri } \\
\text { rukovanju }\end{array}$ & $\begin{array}{l}\text { e) exposure to } \\
\text { light during } \\
\text { storage prior to } \\
\text { testing / } \\
\text { izlaganje } \\
\text { svjetlosti } \\
\text { tijekom } \\
\text { pohrane prije } \\
\text { ispitivanja }\end{array}$ \\
\hline
\end{tabular}

The differences between the strips from different sets of blocks could be caused by drying stresses and the collapse. However, this is generally avoided by the choice of blocks from either naturally seasoned commercial stock or from the freshly fallen tree.

Saturation procedure can cause irreversible changes of the material. There are indications in the literature that the hydrolytic processes in wood are ac- tually very slow at room temperature (Evans and Banks $1988,1990)$ but one should not neglect the possibility that the longer storage in water may cause some degradation of the blocks. Similarly, the amount of ethanol in water and the level of vacuum applied to the blocks may result in differences in swelling and the migration of the resin to the surface, which was observed during the work done by Turkulin (1996). 
Provided that the choice of blocks (the grain angle) and the thickness measurements are performed correctly and results show no great aberrations, the strips should not exhibit structural differences that could significantly reduce the strength. The ray effect or incorrect angle to the radial plane are manifested on individual readings, whereas the grain angle influences the strength of the whole material from one block and is manifested in every batch. In this case the differences between zero and $10 \mathrm{~mm}$ span strength are smaller than usual, the coefficients of variation are greater than usual and this is valid for all the batches in the trial.

The effect of temperature on weathering rates (Derbyshire et al., 1996) is estimated to be much smaller than the effect of light and moisture, and the relative effect of up to $5 \%$ temperature oscillations was empirically shown to be practically negligible (Turkulin, 1996).

The radiation dose and exposure humidity are very influential factors and should be carefully maintained at the desired and constant level during artificial exposures of the strips. Fluorescent lamps exhibit significant differences in the irradiation output along their length, therefore an exposure pattern of rotation and replacement of strip holders should be devised that enables uniform and equal level of radiation dose for all samples in the chamber. A single batch showing significantly lower or greater strength in both zero and 10 $\mathrm{mm}$ span usually indicates the difference in the incident irradiation dose.

Humidity fluctuations during exposure, particularly the presence of liquid water (condensation) may severely affect the degradation of affected material (Figure 8).

The relative humidity of air during exposure and testing is, along with the clamping pressure, probably the most influential factor on testing results and was shown to cause great strength deviations in both zero and $10 \mathrm{~mm}$ span (Turkulin, 1996).

If some strips significantly vary in their physical properties or thickness within the batch, usually only one or two strips show the excessive strength values. Minimum or maximum values for this particular batch exceed by far the usual range. If one block differs from the other two in any characteristics, again 2 or 4 readings in successive batches show excessive strength values. Subsequent examination of the strips yielding unusual strength generally gives answers as to the reasons for irregularities (see micrographs in Figure 7); most often the causes lay in thickness, angle of cutting (ray appearance) and latewood portion aberrations.

\section{CONCLUSIONS}

\section{ZAKLJUČAK}

The microtensile "thin strip" method is a useful and reliable means for the determination of relative mechanical properties on small clear samples, but also the changes induced in wood tissue due to chemical modification, weathering or biological deterioration. However, the method is delicate, may be time-consuming and requires specific skills and instrumentation. Testig material should be chosen very carefully to prevent the intrinsic variabilities of wood to obscure the variable under test. Accuracy and reproducibility of the results greatly depend on preparation procedure, selection of material or number of samples, density, thickness, thickness variability, moisture content and temperature during testing as well as the rate of loading. A strict control of the parameters listed in this paper will improve the accuracy and reliability of results. Nonetheless, having all influential parameters under control, the thin strip method provides excellent scientific tool for various tests of wood properties.

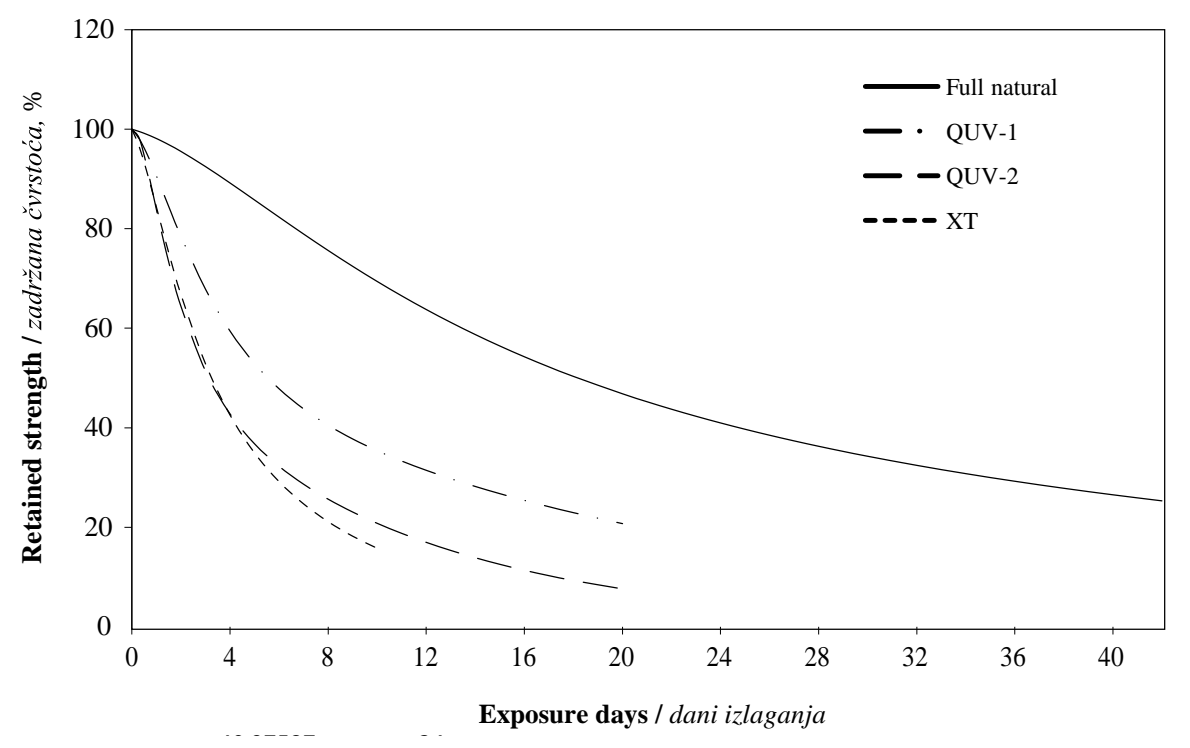

Figure 8 Strength changes of Scots pine sapwood in natural exposure and in artificial weathering regimes (UV and xenon light) of high humidity tested over $10 \mathrm{~mm}$ span

Slika 8. Promjene čvrstoće bjeljike bijele borovine tijekom prirodnog izlaganja i laboratorijskog izlaganja (UV i ksenonskom svjetlu) pri visokoj relativnoj vlažnosti zraka ispitivane na $10 \mathrm{~mm}$ rasponu 
The integration of the results yielded by microtechnique to the gross sample properties is impossible. However, microspecimens serve as useful link between the single fibre and the standard size specimen. Further to that, microtensile testing presents a very beneficial technique as additional analysis method of wood mechanical, chemical and biological properties.

Provided that specimens are of small dimensions so that anatomical differences might be large in comparison with overall dimensional values, the application of the method enables a rapid and reliable means of assessing the complex chemical and structural changes occurring within the surface layers of wood during weathering as well as depth profiling during other degradation or modification processes.

\section{Acknowledgements - Zahvale}

Experimental work was executed in the Building Research Establishment Ltd. (United Kingdom) under auspices of the British Council's and Croatian Ministry of Science's sponsored ALIS project Improving the service life of exterior timber building components (ALIS 984/241). Authors wish to express their gratitude to Dr Hillary Derbyshire, PhD and Dr E. Roy Miller, $\mathrm{PhD}$, for their contribution and supervision of the work.

\section{REFERENCES}

6. LITERATURA

1. Biblis, E. J., 1969: Tensile properties of lobloly pine growth zones. Wood Fiber Sci 1(1): 18-28.

2. Biblis, E. J., 1970: Effect of thickness of microtome sections on their tensile properties. Wood Fiber Sci 2(1): 1930.

3. Derbyshire, H.; Miller, E. R., 1981: The Photodegradation of wood during solar irradiation. Part 1. Effects on the structural integrity of thin wod strips. Holz RohWerkstoff 39: 341-350. http://dx.doi.org/10.1007/ BF02608404

4. Derbyshire, H.; Miller, E. R.; Turkulin, H., 1995: Investigations into the photodegradation of wood using microtensile testing. Part 1: The application of microtensile testing to measurement of photodegradation rates. Holz Roh Werkstoff 53(6): 339-345. http://dx.doi.org/10.1007/ s001070050103

5. Derbyshire, H.; Miller, E. R.; Turkulin, H., 1996: Investigations into photodegradation of wood using microtensile testing. Part 2: An investigation of the changes in tensile strength of different softwood species during antural weathering. Holz Roh Werkstoff 54(1): 1-6. http:// dx.doi.org/10.1007/s001070050123

6. Derbyshire, H.; Miller, E. R.; Turkulin, H., 1997: Investigations into photodegradation of wood using microtensile testing. Part 3: The influence of temperature on photodegradation rates. Holz Roh- Werkstoff 55: 287-291. http://dx.doi.org/10.1007/s001070050229

7. Dinwoodie, J. M., 1966: Induction of cell wall dislocations (slip planes) during the preparation of microscope sections of wood. Nature, 212 (5061): 525-527.

8. Evans, P. D.; Banks, W. B., 1985: Degradation of wood surfaces by dilute acids. IRG document No IRG/ WP/3326. The IRG Secretariat, Stockholm.
9. Evans, P. D.; Banks, W. B., 1988: Degradation of wood surfaces by water. Changes in mechanical properties of thin wood strips. Holz Roh- Werkstoff 46(11): 427-435. http://dx.doi.org/10.1007/BF02608208

10. Evans, P. D.; Banks, W. B., 1990: Degradation of wood surfaces by water. Weight losses and changes in ultrastructural and chemical composition. Holz Roh- Werkstoff 48(3): 159-163. http://dx.doi.org/10.1007/ BF02617767

11. Evans, P. D.; Schmalzl, K. J.; Michell, A. J., 1992a: Rapid loss of lignin at wood surfaces during natural weathering. Doc.IRG/WP/2390-92. IRG Secretariat, Stockholm, Sweden.

12. Evans, P. D.; Michell, A. J.; Schmalzl, K. J., 1992b: Studies of the degradation and protection of wood surfaces. Wood Sci Technol. 26(2): 151-163. http://dx.doi. org/10.1007/BF00194471

13. Forsaith, C. C., 1933: The strength properties of small beams (match stick size) of southern yellow pine. Bull. of the NY State College of Forestry Vol.VI, No.2-a. Syracuse University, Syracuse, New York.

14. Ifju, G.; Kennedy, R. W., 1962: Some variables affecting microtensile strength of douglas-fir. For. Prod. J. 12(5): 213-217.

15. Ifju, G.; Wellwood, R. W.; Wilson, J. W., 1965a: Improved microtechnic for wood tensile strength and related properties. Forest Prod. J. 15(1): 13-14.

16. Ifju, G.; Wellwood, R. W.; Wilson, J. W.; 1965b: Relationship between certain intra-increment measurements in Douglas-fir. Pulp Pap. Mag. Can. 66: T475-T483.

17. Ifju, G., 1964: Tensile strength behavior as a function of cellulose in wood. Forest Prod. J. 21 (8): 366-372.

18. Ifju, G., 1969: Within-growth-ring variation in some physical properties of Southern pine wod. Wood Sci. 2(1): 11-19.

19. Jirouš-Rajković, V.; Turkulin, H.; Miller, E. R., 2004: Depth profile of UV-induced wood surface degradation. Surface coatings international. Part B, Coatings transactions. 87(4): 241-247. http://dx.doi.org/10.1007/ BF02699671

20. Kalnins, M. A., 1966: Surface characteristics of wood as they affect durability of finishes. Part II: Photochemical degradation of wood. US For. Ser. Res. Pap FPL 57: 23 60. Madison: USDA For. Service, Forest Products Laboratory.

21. Keith, C. T.; Côté, W. A. Jr., 1968: Microscopic characterization of slip lines and compression failures in wood cell walls. Forest Prod. J. 18 (3): 67-74.

22. Kennedy, R. W., 1966: Intra-increment variation and heritability of specific gravity, parallel-to-grain tensile strength, stiffness and tracheid length in clonal Norway spruce. Tappi 49 (7): 292-296.

23. Kennedy, R. W., Chan, C. K., 1970: Tensile properties of microsections prepared by different microtomy. J. Inst. Wood Sci. 5(1): 39-42.

24. Kennedy, R. W.; Ifju, G., 1962: Applications of microtensile testing to thin wood sections. Tappi 45(9): 725-733.

25. Kloot, N. H., 1952: A microtesting technique for wood. Aust. J. Appl. Sci. 3(2): 125-143.

26. Kufner, M., 1963: Über die Spannungsverteilung in hölzernen Zugstäben. Holz Roh- Werkstoff 21: 300-305.

27. Law, K. L.; Koran, Z., 1979: Microtensile strength of white spruce wood - a new approach. Wood Sci. 11(4): 221-226.

28. Lehringer, C.; Saake, B.; Živković, V.; Richter, K.; Militz, H., 2011: Effect of Physisporinus vitreus on wood properties of Norway spruce. Part 2: Aspects of micro- 
tensile strength and chemical changes. Holzforschung. 65(5): 721-727. http://dx.doi.org/10.1515/hf.2011.090

29. Mark, R. E., 1965: Tensile stress analysis of the cell walls of coniferous tracheids. In: Côte, W.A. Jr. (Ed.): Cellular Ultrastructure of Woody Plants. Syracuse, NY. Syracuse University Press. 539-549.

30. Mark, R. E., 1967: Cell wall mechanics of tracheids. New Haven and London: Yale University Press. pp 310.

31. Michon, S. G.; Polman, J. E.; Staniszewski, P.; Militz, H., 1994: The use of a microtensile stength bench for testing the strength of growth rings of softwoods and hartwoods parallel to the grain. Holz Roh- Werkstoff 52(3): 176178. http://dx.doi.org/10.1007/BF02615217

32. Nordman, L. S.; Quickström, B., 1969: Variability of the mechanical properties of fibers within a growth period. In: D.H. Page (Ed.): The physics and chemistry of wood pulp fibers. TAPPI STAP Series, No.8. New York: TAPPI, p. 177-201.

33. Pulmac (Technology Series), 1992: Subject: Fiber quality. Pulmac Instruments Int. Inc., Montpelier, VT, USA.

34. Raczkowski, J., 1980: Seasonal effects on the atmospheric corrosion of spruce micro-sections. Hlz Roh-Werkstoff 38: 231-234. http://dx.doi.org/10.1007/BF02607398

35. Turkulin, H., 1996. Photodegradation of exterior timber building components. Ph.D. Thesis, University of Zagreb, Zagreb.

36. Turkulin, H.; Sell, J., 2002: Investigations into the photodegradation of wood using microtensile testing. Part 4: Tensile properties and fractography of weathered wood. Holz Roh Werkstoff 60 (2): 96-195. http://dx.doi. org/10.1007/s00107-002-0282-4

37. Turkulin, H.; Derbyshire, H.; Miller, E. R., 2004: Investigations into the photodegradation of wood using microtensile testing. Part 5: The influence of moisture on photodegradation rates. Holz Roh- Werkstoff 62:307-312. http://dx.doi.org/10.1007/s00107-004-0493-y

38. Turkulin, H.; Arnold, M.; Richter, K.; Strub, E.; JiroušRajković, V.; Mihulja, G., 2006: Hydrophobic treatment for improvement of wood surface durability. Proceedings of the conference: Fifth Woodcoatings Congress: Enhancing Service Life. Prague, Chech Republic, 17-18. October 2006. Paper 20: 1-17. High Street Hampton, UK: Paint Research Association.

39. Wachtel, A. W.; Gettner, M. E.; Ornstein, L., 1966: Microtomy. In: Pollister, A.W. (Ed.): Physical techniques in biological research, 2nd ed., Vol. III, Part A: Cells and tissues. New York and London: Academic Press, pp. 173246.

40. Wardrop, A. B., 1951: Cell wall organization and the properties of the xylem. 1. Cell wall organization and the variation of breaking load in tension of the xylem in conifer stems. Aust. J. Sci. Res. B. 4 (4): 391-414.

41. Wellwood, R. W.; Ifju, G.; Wilson, J. W., 1965: Intra-increment physical properties of certain western Canadian coniferous species. In: Côté, W. A. Jr. (Ed.): Cellular Ultrastructure of Woody Plants. Syracuse, NY. Syracuse University Press. pp. 539-549.

42. Xie, Y.; Krause, A.; Militz, H.; Turkulin, H.; Richter, K.; Mai, C., 2007: Effect of treatments with 1,3-dimethylol-4,5-dihydroxy-ethyleneurea (DMDHEU) on the tensile properties of wood. Holzforschung 61 (1): 43-50. http://dx.doi.org/10.1515/HF.2007.008

43. Ylinen, A., 1942: Über den Einfluss des Spätholzeinteils und der Rohwichte auf die Festigkeits- und elastischen Eigenschaften des Nadelholzes. Acta Forestalia Fennica 50 (5): 1-29.

44. Živković, V., 2011: Activation spectra in photodegradation of wood. Doctoral tesis. University of Zagreb - Faculty of Forestry, Zagreb.

Corresponding address:

Assist. VJEKOSLAV ŽIVKOVIĆ, Ph.D.

Department for Furniture and Wood Products

Faculty of Forestry, University of Zagreb

Svetošimunska 25

10002 Zagreb, Croatia

e-mail: zivkovic@sumfak.hr 